DOI: $10.15193 /$ zntj/2017/113/211

\author{
ANNA SADOWSKA, EWA DYBKOWSKA, RITA RAKOWSKA, \\ EWELINA HALLMANN, FRANCISZEK ŚWIDERSKI
}

\title{
OCENA ZAWARTOŚCI SKLADNIKÓW BIOAKTYWNYCH I WLAŚCIWOŚCI PRZECIWUTLENIAJĄCYCH PROSZKÓW WYPRODUKOWANYCH METODĄ LIOFILIZACJI Z WYBRANYCH SUROWCÓW ROŚLINNYCH
}

\begin{abstract}
Streszczenie
Celem pracy była ocena zawartości witaminy C, polifenoli i karotenoidów oraz określenie aktywności przeciwutleniającej proszków wyprodukowanych w warunkach przemysłowych z wybranych surowców roślinnych w procesie liofilizacji, a następnie poddanych mikronizacji. Zbadano 12 proszków: owocowych, warzywnych, z pokrzywy i trawy jęczmiennej, cieszących się coraz większym zainteresowaniem konsumentów. Zawartość witaminy $\mathrm{C}$, frakcji polifenoli i karotenoidów w proszkach oznaczono metodą wysokosprawnej chromatografii cieczowej HPLC, aktywność przeciwutleniającą - metodą spektrofotometryczną z zastosowaniem syntetycznego kationorodnika ABTS ${ }^{+}$.

W zależności od rodzaju badanych surowców roślinnych wytworzone proszki charakteryzowały się zróżnicowaną, dość dużą zawartością badanych substancji bioaktywnych oraz aktywnością przeciwutleniającą. Najwięcej witaminy $\mathrm{C}$ zawierały proszki z owoców rokitnika i z jarmużu (odpowiednio: 333 i $348 \mathrm{mg} / 100 \mathrm{~g}$ ) oraz proszki z mieszanki czerwonych owoców i warzyw (średnio $486 \mathrm{mg} / 100 \mathrm{~g}$ ). Największą zawartością polifenoli ogółem oraz najwyższą aktywnością przeciwutleniającą charakteryzowały się proszki z aronii i borówki czernicy.

Na podstawie uzyskanych wyników badań stwierdzono, że otrzymane proszki, w zależności od ich rodzaju, mogą być wykorzystywane do produkcji żywności funkcjonalnej, żywności specjalnego przeznaczenia żywieniowego i suplementów diety nie tylko ze względu na swoje walory sensoryczne, ale także z uwagi na zawartość cennych składników: naturalnej witaminy C, polifenoli i karotenoidów.
\end{abstract}

Słowa kluczowe: liofilizacja, witamina C, polifenole, aktywność przeciwutleniająca, proszki

Dr inż. A. Sadowska, dr inż. E. Dybkowska, dr inż. R. Rakowska, dr hab. E. Hallmann, prof. dr hab. F. Świderski, Katedra Żywności Funkcjonalnej, Ekologicznej i Towaroznawstwa, Wydz. Nauk o Żywieniu Człowieka i Konsumpcji, Szkoła Główna Gospodarstwa Wiejskiego w Warszawie, ul. Nowoursynowska159C,02-776 Warszawa.Kontakt: ewa.dybkowska@wp.pl 


\section{Wprowadzenie}

Żywność pochodzenia roślinnego stanowi bogate źródło związków o właściwościach przeciwutleniających, do których zalicza się polifenole (kwasy fenolowe, flawonoidy i antocyjany), a także karotenoidy, kwas askorbinowy i tokoferole. Zaleca się systematyczne spożywanie warzyw i owoców bogatych w przeciwutleniacze, gdyż odgrywają one istotną rolę w profilaktyce wielu chorób, m.in. miażdżycy i nowotworów, ze względu na zdolność neutralizacji szkodliwego działania aktywnych form tlenu. Część owoców i warzyw dostępna jest przez stosunkowo krótki okres w sezonie letnim i jesiennym, dlatego szczególne znaczenie mają metody przetwarzania tych cennych, ale nietrwałych surowców. Jednym ze sposobów jest proces suszenia. Do produkcji żywności sproszkowanej, m.in. koncentratów potraw, herbatek owocowych, odżywek czy suplementów diety stosowane są owoce i warzywa w postaci proszków otrzymywanych metodą suszenia konwekcyjnego, a w ostatnich latach - metodą liofilizacji surowca, a następnie jego rozdrabniania. W przypadku proszków owocowych stosuje się zwykle suszenie rozpyłowe soków, w którym niezbędne jest stosowanie dodatku nośnika (maltodekstryny) w ilości $60 \div 70 \%$ [24]. Obserwuje się duży popyt na proszki otrzymywane metodą liofilizacji, a następnie rozdrabniania. Liofilizacja jest procesem, którego celem jest usunięcie wody z zamrożonego produktu w wyniku sublimacji lodu. Proces przebiega $\mathrm{w}$ temperaturze poniżej $0{ }^{\circ} \mathrm{C}$ i pod zmniejszonym ciśnieniem. Ze względu na zastosowanie niskich temperatur podczas procesu liofilizacji uzyskuje się produkt o dobrej jakości i trwałości, gdyż większość reakcji mikrobiologicznych i chemicznych zostaje zahamowana. Suszenie odbywa się bez udziału powietrza, dlatego procesy utleniania są ograniczone. Liofilizacja umożliwia otrzymanie suszonych owoców i warzyw o znacznie wyższej jakości niż przy zastosowaniu suszenia konwekcyjnego. Produkty liofilizowane zachowują naturalną barwę, zapach i smak. Struktura produktów poddanych liofilizacji jest porowata i krucha, a po uwodnieniu charakteryzuje się właściwościami przybliżonymi do surowca, w przeciwieństwie do suszy konwekcyjnych, które wykazują obniżoną zdolność rehydratacji. Wykorzystanie liofilizacji ograniczają względy ekonomiczne związane $\mathrm{z}$ wysokimi kosztami. Uznaje się, że proces liofilizacji powoduje najmniejsze straty związków bioaktywnych i ich właściwości przeciwutleniających. Liofilizacja uważana jest za najlepszy sposób na zachowanie wartości odżywczej suszonych produktów. Metoda ta wymaga specjalnych warunków pakowania i przechowywania z uwagi na wysoką higroskopijność produktów liofilizowanych $[7,11,13,16,25]$. Niektórzy autorzy twierdzą jednak, że proces ten może powodować znaczną stratę związków bioaktywnych $[21,28]$. Niezbędny przy otrzymywaniu proszków proces mikronizacji liofilizowanych surowców może powodować również znaczne straty składników bioaktywnych, a szczególnie witaminy $\mathrm{C}$. Niewiele jest danych literaturowych dotyczących zawartości związków bioaktywnych w proszkach otrzymywanych z surowców liofilizowanych, 
a następnie mikronizowanych. Istniejące dane dotyczą zwykle surowców oraz niektórych liofilizatów bez procesu ich mikronizacji. Brak jest również danych dotyczących zawartości tych związków w wielu surowcach spośród badanych w niniejszej pracy. W badaniach dotyczących zawartości witaminy $\mathrm{C}$ i polifenoli w proszkach otrzymywanych metodą liofilizacji i rozdrabniania Sadowska i wsp. [24] wykazali dużo witaminy $\mathrm{C}$ w jarmużu i dużą zawartość polifenoli w aronii. Ocena jakości produktów suszonych z zastosowaniem liofilizacji prowadzona przez innych autorów wskazywała na dużą zawartość polifenoli w liofilizowanych owocach aronii [5], a także w owocach borówki czernicy [8], przy czym uzyskane wartości były w znacznym stopniu zróżnicowane.

Celem pracy była ocena zawartości związków bioaktywnych (witaminy $\mathrm{C}$, polifenoli i karotenoidów) w proszkach wyprodukowanych w warunkach przemysłowych przez liofilizację wybranych surowców pochodzenia roślinnego z grupy owoców i warzyw, a także pokrzywy i trawy jęczmiennej i ich mikronizację $\mathrm{w}$ warunkach przemysłowych oraz określenie ich właściwości przeciwutleniających.

\section{Material i metody badań}

Materiał doświadczalny stanowiły proszki otrzymane w procesie liofilizacji surowców pochodzenia roślinnego. Zbadano łącznie 12 proszków. Oceniano liofilizowane proszki z owoców: aronii, borówki czernicy, rokitnika zwyczajnego, żurawiny, z warzyw: buraka, jarmużu, szpinaku oraz z pokrzywy i trawy jęczmiennej, a także komercyjne mieszaniny proszków (Lyo Food Sp. z o.o., Polska):

- „mieszankę czerwonych owoców” zawierającą liofilizowane truskawki (29 \%), banany (29\%), brzoskwinie (21\%), czarne porzeczki (14\%), żurawinę 7 (\%);

- „mieszankę czerwonych owoców i warzyw” zawierającą: liofilizowane truskawki (53\%), czarne porzeczki (35\%) i buraki (12\%);

- „mieszankę zielonych owoców i warzyw” zawierającą liofilizowane surowce: jabłka (35\%), kiwi (35\%), ananasy (21\%), szpinak (4\%), pokrzywę (4\%), imbir (1\%).

Surowce zbierane były w fazie dojrzałości zbiorczej i pochodziły od plantatorów krajowych i z zakupów rynkowych. Do procesu liofilizacji stosowano surowce w fazie dojrzałości konsumpcyjnej. Liofilizację zamrożonych surowców (w temp. $-30{ }^{\circ} \mathrm{C}$ ) prowadzono przy użyciu liofilizatora typu LV70 (PPUH Lyovit, Polska) w temp. $-50{ }^{\circ} \mathrm{C}$, pod ciśnieniem $10 \mathrm{~Pa}$, temp. półek $50{ }^{\circ} \mathrm{C}$. Wysuszony materiał poddawano rozdrabnianiu w młynie typu MUKF100 (PP Młynpol, Polska) do cząstek wielkości poniżej $630 \mu \mathrm{m}$. Do czasu przeprowadzenia analiz proszki przechowywano w opakowaniach barierowych typu doypack, wykonanych z laminatów wielowarstwowych.

Metody badań obejmowały oznaczanie zawartości witaminy $\mathrm{C}$, polifenoli ogółem, różnych frakcji polifenoli, karotenoidów, zawartości suchej masy oraz. właściwo- 
ści przeciwutleniających. Witaminę C jako sumę kwasu askorbinowego i kwasu dehydroaskorbinowego oznaczano metodą wysokosprawnej chromatografii cieczowej z detekcją UV przy długości fali $\lambda=245 \mathrm{~nm}$ i szybkością przepływu fazy ruchomej $0,8 \mathrm{ml} / \mathrm{min}$. W celu określenia całkowitej zawartości witaminy $\mathrm{C}$ w próbkach prowadzono ekstrakcję przez redukcję kwasu askorbinowego do dehydroaskorbinowego za pomocą ditiotreitolu. Analizę prowadzono przy użyciu chromatografu cieczowego UV 2487 z detektorem wodnym i kolumną RP Symmetry C18, $5 \mu \mathrm{m}, 4,6 \times 150 \mathrm{~mm}$ (Shimadzu, Japonia), temp. kolumny $25^{\circ} \mathrm{C}$, objętość wstrzyknięcia 10 - $30 \mu 1$.

Zawartość i skład polifenoli (flawonoidów, antocyjanów i kwasów fenolowych) oraz karotenoidów oznaczano metodą wysokosprawnej chromatografii cieczowej HPLC, z identyfikacją poszczególnych związków fenolowych na podstawie wyznaczonych czasów retencji substancji wzorcowych Fluka i Sigma-Aldrich (USA) przy użyciu chromatografu cieczowego HPLC firmy Shimadzu (Japonia) składającego się z 2 pomp LC-20AD, systemu kontrolerów CMB-20A, autosamplera SIL-20AC, detektora UV/VIS SPD-20AV, kontrolera CTD-20AC. Podczas oznaczania polifenoli próbki ekstrahowano metanolem i rozdzielano w kolumnie w układzie gradientowym (mieszanina acetonitrylu z wodą dejonizowaną - faza A: $10 \%$ acetonitrylu, $90 \%$ wody dejonizowanej; faza B: $55 \%$ acetonitrylu i $45 \%$ wody dejonizowanej) o pH 3. Oznaczona zawartość polifenoli jest sumą związków oznaczonych chromatograficznie. Zawartość antocyjanów oznaczano po ekstrakcji próbek w metanolu i kwasie solnym. Mieszaninę rozdzielano $\mathrm{w}$ kolumnie pod wpływem fazy ruchomej (mieszanina 5-procentowego kwasu octowego, metanolu i acetonitrylu w stosunku $70: 10: 20$ ). Zawartość karotenoidów oznaczano poprzez ekstrakcję próbek w acetonie i rozdzielanie pod wpływem fazy ruchomej (faza A: 10-procentowy acetonitryl i metanol w stosunku 90 : 10; faza B: metanol i octan etylu 34 : 16). Używano kolumny Synergi Fusion-RP 80i $(250 \times 4,60 \mathrm{~mm})$ - Phenomenex, USA, zgodnie z metodyką opisaną przez Sadowską i wsp. [24]. Aktywność przeciwutleniającą oznaczano spektrofotometrycznie przy użyciu syntetycznego kationorodnika $\mathrm{ABTS}^{+}$zgodnie $\mathrm{z}$ metodyką opisaną przez Pellegrini i wsp. [19]. Zawartość suchej masy w proszkach oznaczano metodą wagową.

Wyniki poddano analizie statystycznej w programie Statistica v. 10,0 (StatSoft). Zastosowano jednoczynnikową analizę wariancji (ANOVA). Istotność różnic między wartościami średnimi cech jakościowych porównywanych proszków weryfikowano za pomocą testu Duncana $(\mathrm{p}=0,05)$. 


\section{Wyniki i dyskusja}

\section{Zawartość witaminy $C$ w proszkach}

Proszki wyprodukowane metodą liofilizacji z surowców roślinnych charakteryzowały się znacznie zróżnicowaną zawartością witaminy C (tab. 1). Zawartość tej witaminy była bardzo duża w liofilizowanym proszku z jarmużu i owoców rokitnika wynosiła odpowiednio: 347,8 i $333 \mathrm{mg} / 100$ g. Również dużą zawartość tej witaminy stwierdzono w komercyjnych proszkach zawierających w składzie mieszaninę wybranych surowców owocowo-warzywnych $(205,9 \div 486,2 \mathrm{mg} / 100 \mathrm{~g})$ oraz w liofilizowanym proszku z żurawiny $(143,8 \mathrm{mg} / 100 \mathrm{~g})$. Najmniejszą zawartością witaminy C cechował się liofilizowany proszek $\mathrm{z}$ buraków i borówek odpowiednio: 15,4 i $18,8 \mathrm{mg} / 100 \mathrm{~g}$ oraz z aronii $-58,1 \mathrm{mg} / 100 \mathrm{~g}$.

Tabela 1. Zawartość witaminy $\mathrm{C}$ w proszkach wyprodukowanych metodą liofilizacji z wybranych surowców pochodzenia roślinnego

Table 1. Content of vitamin $\mathrm{C}$ in powders produced from selected raw materials of plant origin by freeze-drying

\begin{tabular}{||l|c||}
\hline \multicolumn{1}{|c|}{ Produkt sproszkowany / Powdered product } & Witamina C / Vitamin C [mg/100 g] \\
\hline Aronia / Chokeberry & $58,1^{\mathrm{b}} \pm 0,1$ \\
\hline Borówka czernica / Bilberry & $18,8^{\mathrm{a}} \pm 0,6$ \\
\hline Rokitnik / Sea buckhorn & $333,0^{\mathrm{f}} \pm 9,6$ \\
\hline Żurawina / Cranberry & $143,8^{\mathrm{c}} \pm 6,8$ \\
\hline Burak / Beetroot & $15,4^{\mathrm{a}} \pm 3,7$ \\
\hline Jarmuż / Kale & $347,8^{\mathrm{g}} \pm 19,2$ \\
\hline Mieszanka czerwonych owoców / Red fruit mix & $205,9^{\mathrm{d}} \pm 16,1$ \\
\hline $\begin{array}{l}\text { Mieszanka czerwonych owoców i warzyw } \\
\text { Red fruit and vegetables mix }\end{array}$ & $486,2^{\mathrm{h}} \pm 7,6$ \\
\hline $\begin{array}{l}\text { Mieszanka zielonych owoców i warzyw } \\
\text { Green fruit and vegetables mix }\end{array}$ & $221,8^{\mathrm{e}} \pm 4,2$ \\
\hline \hline
\end{tabular}

Objaśnienia / Explanatory notes:

W tabeli przedstawiono wartości średnie \pm odchylenia standardowe / Table shows mean values \pm standard deviations; a, b, c, d - wartości średnie oznaczone różnymi literami różną się statystycznie istotnie $(\mathrm{p} \leq 0,05) /$ mean values denoted by different letters differ statistically significantly $(\mathrm{p} \leq 0.05)$.

W literaturze niewiele jest danych dotyczących zawartości witaminy $\mathrm{C}$ w proszkach otrzymywanych metodą liofilizacji i odnoszą się one do świeżych surowców bądź do liofilizowanego surowca. Uzyskane wyniki zawartości witaminy $\mathrm{C} w$ liofilizowanych proszkach z jarmużu i aronii były zbliżone do uzyskanych przez Sadowską i wsp. [24] w badaniach, w których zawartość witaminy C w proszkach z jarmużu i aronii, otrzymanych metodą liofilizacji przy użyciu liofilizatora laboratoryjnego i temp. półek $20{ }^{\circ} \mathrm{C}$, wynosiła odpowiednio [mg/100 g s.m.]: 347,84 i 58,10. Surowcem szczególnie 
bogatym w witaminę $C$ jest jarmuż, gdyż zawiera jej $23 \div 150 \mathrm{mg} / 100 \mathrm{~g}$ w świeżym surowcu [1,9], a także owoce rokitnika zawierające $52,86 \div 130,97 \mathrm{mg} / 100 \mathrm{~g}$ kwasu askorbinowego w świeżym surowcu [26].

Dane dotyczące zawartości witaminy $\mathrm{C}$ w produktach liofilizowanych są dość rozbieżne. Niektórzy autorzy podają, że proces liofilizacji nie wpływa lub wpływa tylko nieznacznie na zawartość witaminy $\mathrm{C}$ w liofilizowanych produktach. Lin i wsp. [12] nie stwierdzili istotnego wpływu liofilizacji na poziom witaminy $\mathrm{C} w$ marchwi w przeciwieństwie do suszenia konwekcyjnego, po którym nastąpiło zmniejszenie zawartości witaminy C o $62 \%$. Marques i Freire [14] uzyskali małe straty witaminy C w liofilizowanych owocach tropikalnych. Bober i Oszmiański [2] odnotowali jednak straty witaminy $\mathrm{C} w$ wytłokach $\mathrm{z}$ aronii poddanych liofilizacji na poziomie $60 \%$, a poddane suszeniu konwekcyjnemu - do $80 \%$. Straty witaminy C w proszkach otrzymanych przez liofilizację mogą być związane z mechanicznym rozdrabnianiem materiału liofilizowanego, w czasie którego materiał narażony jest na dostęp tlenu atmosferycznego. Straty te można zmniejszyć, stosując rozdrabnianie w kontrolowanych warunkach bez tlenu.

Produkty liofilizowane charakteryzują się małą zawartością wody. W badanych mikronizowanych liofilizatach zawartość wody była bardzo zbliżona i wynosiła 2,5 \pm $0,5 \%$. Zawartość witaminy $\mathrm{C}$ w liofilizatach o tak dużej zawartości suchej masy, mimo znacznych jej strat, była duża. Spożywając 15-gramową porcję proszków warzywnych lub owocowych można pokryć znaczną część zapotrzebowania na naturalną, wysoko przyswajalną witaminę C. Porcja liofilizowanego proszku z jarmużu i owoców rokitnika pokrywa powyżej $80 \%$ zapotrzebowania, żurawiny - powyżej $30 \%$, natomiast aronii $-15 \%$.

\section{Zawartość polifenoli i aktywność przeciwutleniająca proszków}

Zawartość polifenoli i karotenoidów w proszkach z surowców pochodzenia roślinnego przedstawiono $\mathrm{w}$ tab. 2., 3. i 4. Proszki otrzymane $\mathrm{z}$ owoców charakteryzowały się dużą zawartością polifenoli, przewyższającą znacznie ich zawartość w badanych proszkach warzywnych. Największą zawartość tych związków wykazano w liofilizowanych proszkach owocowych z aronii i borówki czernicy - odpowiednio [mg/100 g]: 1876 i 1768 . W żurawinie stwierdzono również znaczną zawartość polifenoli wynoszącą $620 \mathrm{mg} / 100 \mathrm{~g}$. Jarmuż i pokrzywa zawierały ich odpowiednio [mg/100 g]: 361,45 i 238,32. W liofilizowanych proszkach z trawy jęczmiennej i szpinaku wartości te były niższe (odpowiednio: 193,96 i 149,38 mg/100 g), natomiast najmniejszą zawartość polifenoli stwierdzono $\mathrm{w}$ proszku $\mathrm{z}$ buraków i rokitnika zwyczajnego (odpowiednio: 70,42 i $64,38 \mathrm{mg} / 100 \mathrm{~g}$ ). W liofilizowanym proszku z buraków oznaczono zawartość betacyjanów na poziomie $456,72 \mathrm{mg} / 100 \mathrm{~g}$. 


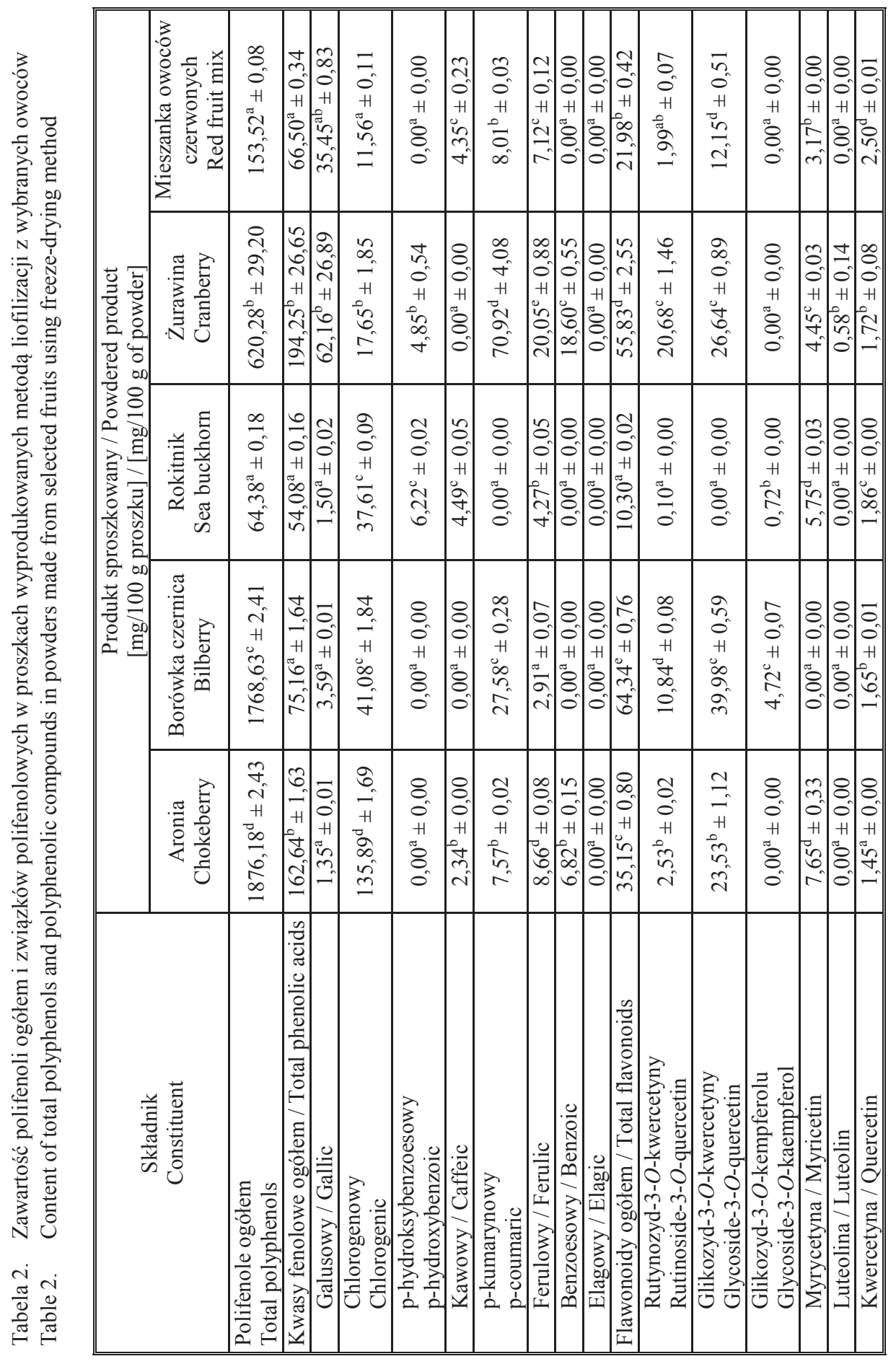




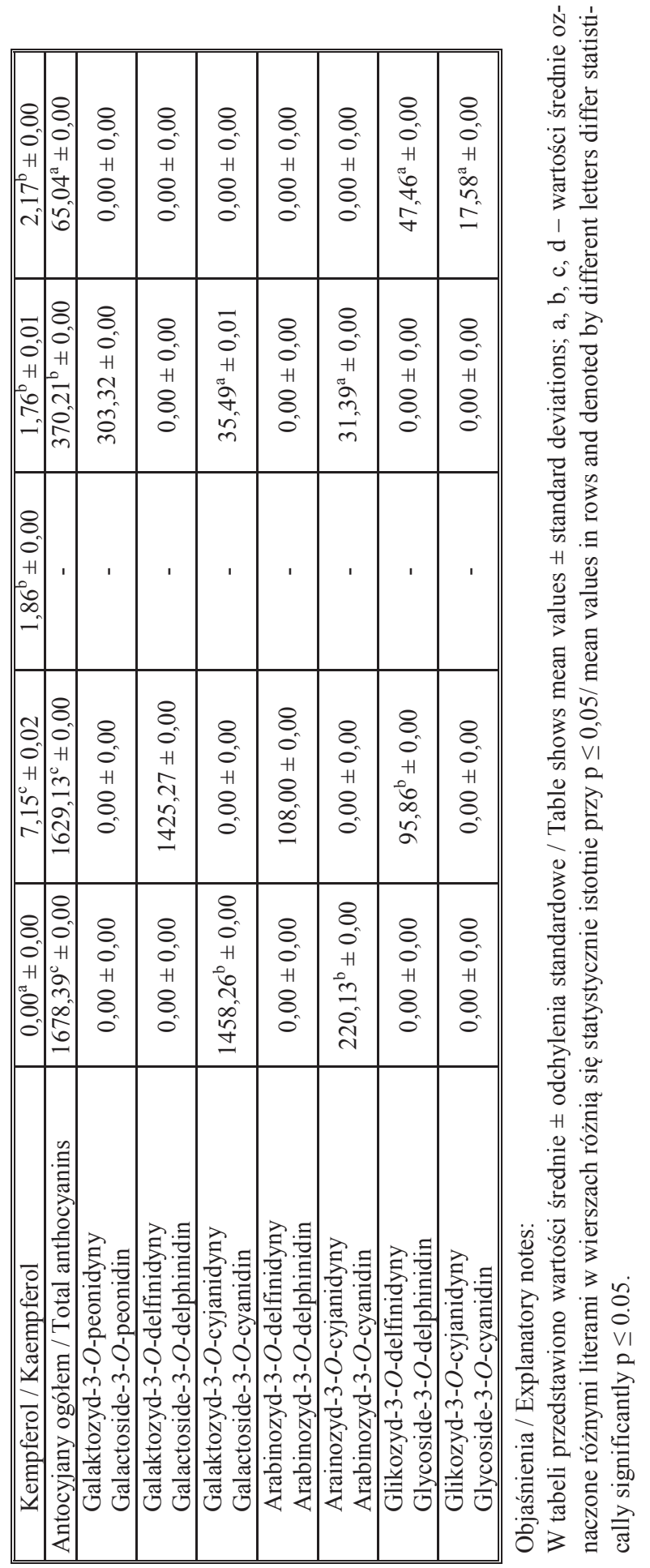




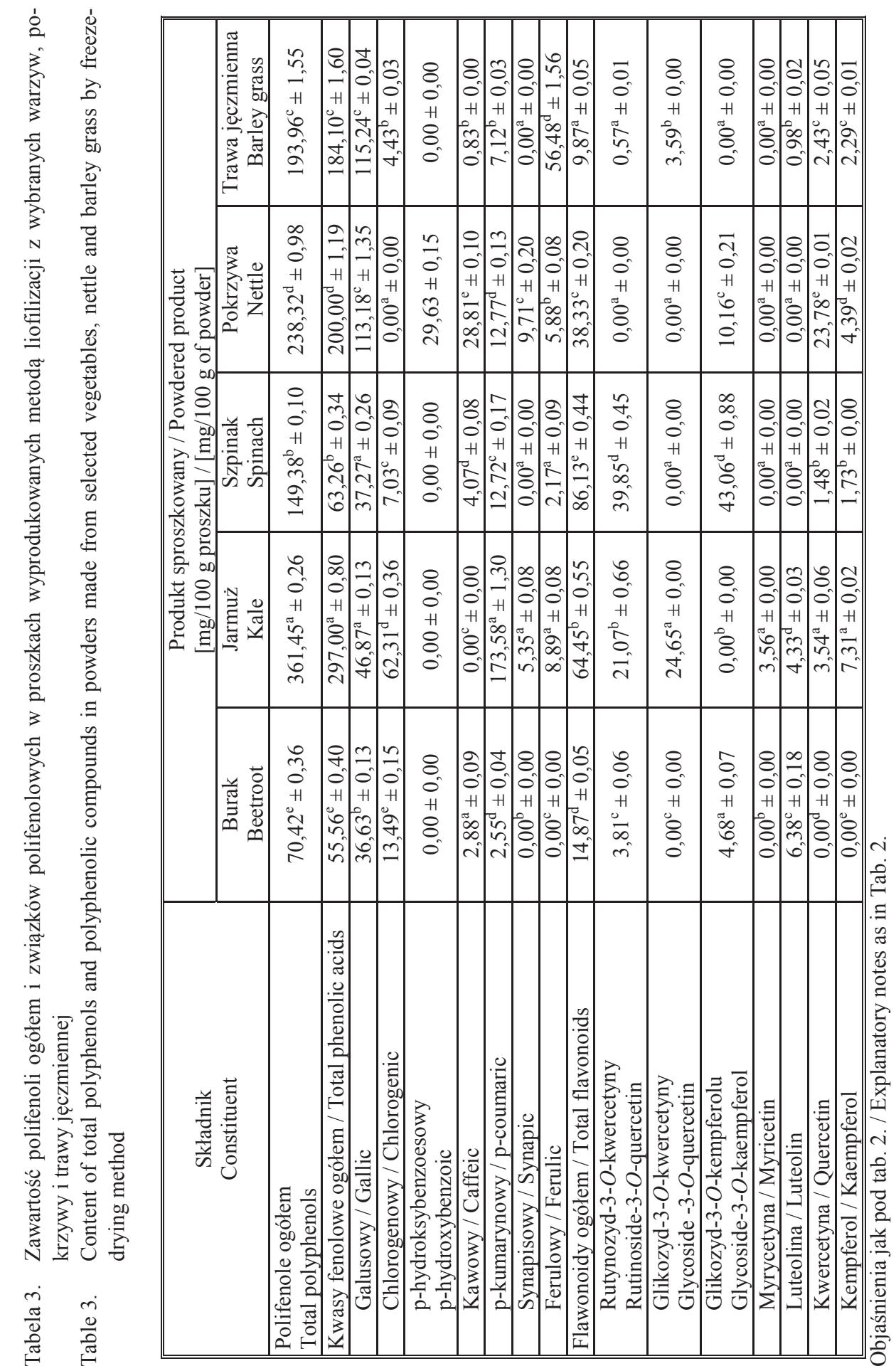




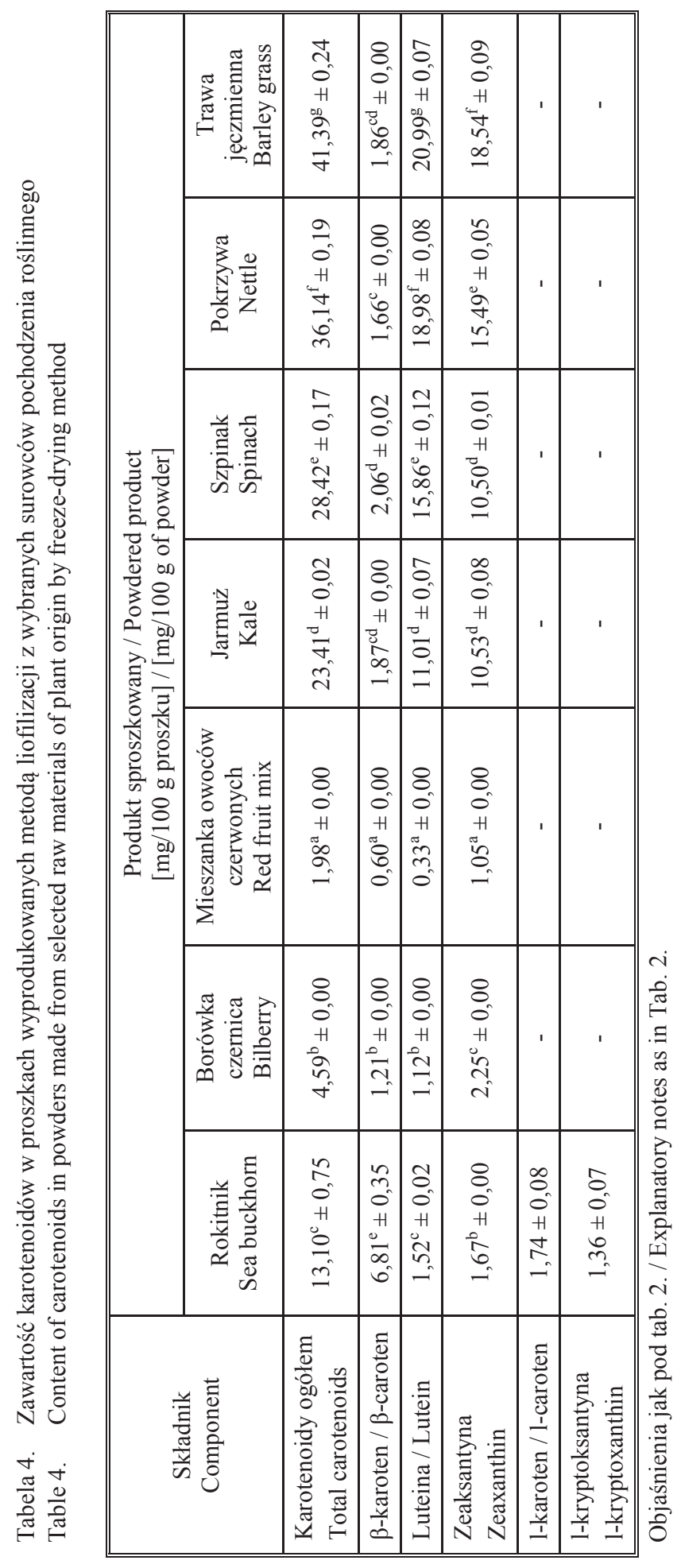


Porównanie uzyskanych wyników zawartości polifenoli i karotenoidów z danymi innych autorów prowadzi do stwierdzenia, że proszki otrzymane w badaniach własnych metodą przemysłowej liofilizacji surowca, a następnie mikronizowania, charakteryzowały się większą zawartością tych związków. Uzyskane wartości w przypadku badań własnych były wynikiem zastosowania metody chromatografii cieczowej, która pozwala na określenie zawartości związków karotenoidowych i polifenoli ogółem z większą dokładnością, w tym zawartości związków wchodzących w ich skład, takich jak: kwasy fenolowe, flawonoidy oraz antocyjany. Dane literaturowe odnoszą się głównie do oznaczania zawartości polifenoli ogółem mniej dokładną metodą spektrofotometryczną, polegającą na przeprowadzeniu reakcji barwnej związków o charakterze polifenoli i pomiarze absorbancji powstających kompleksów za pomocą spektrofotometru. W badaniach Sadowskiej i wsp. [24] dotyczących zawartości polifenoli oznaczonych w liofilizowanych proszkach z aronii i jarmużu uzyskano nieco inne wyniki do uzyskanych w niniejszej pracy. Stwierdzono większą zawartość polifenoli w owocach aronii $(3005,89 \mathrm{mg} / 100 \mathrm{~g}$ s.m.), natomiast mniejszą - w jarmużu $(184,36 \mathrm{mg} / 100 \mathrm{~g} \mathrm{s.m.}$ ), co mogło wynikać z różnic odmianowych wykorzystywanych surowców roślinnych. Mniej polifenoli wykazały Gramza-Michałowska i CzłapkaMatyasik [5] w liofilizowanych przekąskach z aronii (1480 mg GAE/100 g). Zawartość polifenoli ogółem w liofilizowanych owocach borówki czernicy, oznaczona przez Kluszczyńską i Sowińską [8], wynosząca 1638,5 mg GAE/100 g produktu była porównywalna z oznaczoną w badaniach własnych.

Analizowane $\mathrm{w}$ pracy produkty owocowe poddane liofilizacji charakteryzowały się dużą zawartością antocyjanów (tab. 2), zwłaszcza proszki z owoców aronii i borówki czernicy (odpowiednio: 1678 i 1629 mg/100 g), a także z żurawiny $(370 \mathrm{mg} / 100 \mathrm{~g})$. Spośród antocyjanów w proszku z owoców aronii występował głównie galaktozyd-3-O-cyjanidyny, który stanowił $86,88 \%$ zawartości tych związków, natomiast borówka czernica zawierała przede wszystkim galaktozyd-3-O-delfinidyny (stanowił 87,49 \% antocyjanów). Również Dembczyński i wsp. [3] w ekstraktach z owoców aronii zidentyfikowali barwniki antocyjanowe, pochodne cyjanidyny. W największej ilości występował cyjanidyno-3-O-galaktozyd, który stanowił ok. $66,21 \%$ wszystkich antocyjanów. Podobnie Jakobek i wsp. [6] wskazali na przewagę cyjanidyno-3-O-galaktozydu $(279,47 \mathrm{mg} / 100 \mathrm{~g})$, który stanowił $68,9 \%$ wszystkich antocyjanów aronii. Dużą zawartość antocyjanów w owocach aronii, w zakresie $307 \div$ $1480 \mathrm{mg} / 100 \mathrm{~g}$ świeżych owoców i $641 \div 1959 \mathrm{mg} / 100 \mathrm{~g}$ suchej masy, potwierdzają inni autorzy [10]. Źródłem antocyjanów są owoce aronii, czarnej porzeczki, winogron, borówki czernicy oraz bzu czarnego. Szczególnie bogatym źródłem antocyjanów wśród surowców roślinnych są owoce aronii czarnoowocowej. Frejnagel [4] podaje, że ekstrakty z owoców aronii czarnoowocowej i jagody kamczackiej zawierały znaczne ilości antocyjanów (odpowiednio [mg/100 g s.m.]: 40450 i 32150. Nawirska i wsp. 
[15] wykazali bardzo dużą zawartość antocyjanów $\mathrm{w}$ wytłokach $\mathrm{z}$ aronii $12298 \mathrm{mg} / 100 \mathrm{~g}$, natomiast $\mathrm{w}$ wytłokach $\mathrm{z}$ jagód kamczackich, czarnej porzeczki i truskawek ich zawartość wynosiła odpowiednio [mg/100 g]: 9897, 5019 i 671. Sablani i wsp. [23] stwierdzili, że suszenie owiewowe powoduje znaczne zmniejszenie zawartości antocyjanów, związków fenolowych i aktywności przeciwutleniającej w jagodach. Zastosowanie blanszowania przed suszeniem wpływa na poprawę usuwania wilgoci z suszonego surowca, tym samym skraca czas suszenia, co przyczynia się do lepszego zachowania związków fitochemicznych. Bober i Oszmański [2] zwrócili uwagę na większą zawartość barwników antocyjanowych w wyciągu wodnym z liofilizowanych wytłoków z aronii $(34,21 \mathrm{mg} / 100 \mathrm{~g})$ niż w wyciągu $\mathrm{z}$ owoców suszonych owiewowo $(2,36 \mathrm{mg} / 100 \mathrm{~g})$. Autorzy potwierdzili degradujący wpływ wysokiej temperatury na barwniki antocyjanowe, które są wrażliwe także na tlen. Polifenole wykazują niską odporność na czynniki zewnętrzne, takie jak światło, tlen i temperatura [17], dlatego bardzo ważne jest, aby zapobiegać stratom zawartości antocyjanów zarówno podczas suszenia - przez stosowanie metod z ograniczonym wykorzystaniem wyższych temperatur i dostępu tlenu, jak również zadbać o odpowiednie opakowanie produktów zaraz po zakończeniu procesu ich suszenia.

Zawartość karotenoidów w analizowanych proszkach wyprodukowanych metodą liofilizacji wynosiła $1,98 \div 41,39 \mathrm{mg} / 100 \mathrm{~g}$ i była największa w sproszkowanej trawie jęczmiennej i pokrzywie (tab. 4). Proszki z trawy jęczmiennej, pokrzywy, szpinaku i jarmużu zawierały ksantofile: luteinę i zeaksantynę, a także niewielkie ilości $\beta$-karotenu. Spośród analizowanych surowców liofilizowane owoce rokitnika wyróżniały się największą zawartością $\beta$-karotenu $(6,81 \mathrm{mg} / 100 \mathrm{~g})$. Także inni autorzy zwrócili uwagę na zawartość karotenoidów, szczególnie $\beta$-karotenu w rokitniku [20, 26].

Aktywność przeciwutleniająca oznaczana przy użyciu kationorodnika ABTS ${ }^{+}$ w badanych proszkach była wysoka (tab. 5). W przypadku proszku z owoców aronii i borówki czernicy wynosiła odpowiednio: 56,32 i 46,70 mmol Troloxu/100 g, a żurawiny, szpinaku i pokrzywy - odpowiednio [mmol Troloxu/100 g]: 40,39, 38,46 i 36,29. Niższą wartością charakteryzował się proszek z buraka - 31,44 mmol Troloxu/100 g.

Po porównaniu uzyskanych wyników właściwości przeciwutleniających z danymi literaturowymi można stwierdzić, że proszki otrzymywane w warunkach przemysłowych z surowców pochodzenia roślinnego metodą liofilizacji, a następnie mikronizacji, charakteryzowały się aktywnością przeciwutleniającą podobną do uzyskanej przez innych autorów. W badaniach Sadowskiej i wsp. [24] aktywność przeciwutleniająca liofilizowanych proszków z owoców aronii wynosiła 55,64 mmol Troloxu/100 g, a z jarmużu - 31,88 mmol Troloxu/100 g, co jest porównywalne z wynikami uzyskanymi w niniejszej pracy. 
Tabela 5. Aktywność przeciwutleniająca proszków wyprodukowanych metodą liofilizacji z wybranych surowców pochodzenia roślinnego

Table 5. Antioxidant activity of powders made from selected raw materials of plant origin by freezedrying method

\begin{tabular}{||l|c||}
\hline \multicolumn{1}{|c|}{$\begin{array}{c}\text { Produkt sproszkowany } \\
\text { Powdered product }\end{array}$} & $\begin{array}{c}\text { Aktywność przeciwutleniająca / Antioxidant activity } \\
{[\mathrm{mmol} \text { Troloxu/100 g] }}\end{array}$ \\
\hline Aronia / Chokeberry & $56,32^{\mathrm{h}} \pm 0,35$ \\
\hline Borówka czernica / Bilberry & $46,70^{\mathrm{g}} \pm 1,03$ \\
\hline Rokitnik / Sea buckhorn & $33,68^{\mathrm{b}} \pm 0,35$ \\
\hline Zurawina / Cranberry & $40,39^{\mathrm{e}} \pm 0,31$ \\
\hline Burak / Beetroot & $31,44^{\mathrm{a}} \pm 1,22$ \\
\hline Jarmuż / Kale & $34,23^{\mathrm{b}} \pm 0,32$ \\
\hline Szpinak / Spinach & $38,46^{\mathrm{d}} \pm 0,50$ \\
\hline Pokrzywa / Nettle & $36,29^{\mathrm{c}} \pm 0,56$ \\
\hline Trawa jęczmienna / Barley grass & $35,36^{\mathrm{c}} \pm 0,31$ \\
\hline $\begin{array}{l}\text { Mieszanka czerwonych owoców i warzyw } \\
\text { Red fruit and vegetables mix }\end{array}$ & $42,35^{\mathrm{f}} \pm 0,57$ \\
\hline $\begin{array}{l}\text { Mieszanka zielonych owoców i warzyw } \\
\text { Green fruit and vegetables mix }\end{array}$ & $33,20^{\mathrm{b}} \pm 0,30$ \\
\hline \hline
\end{tabular}

Objaśnienia jak pod tab. 1. / Explanatory notes as in Tab. 1.

Aktywność przeciwutleniająca surowców roślinnych była przedmiotem wielu badań. Kulling i Rawel [10] po przeanalizowaniu danych literaturowych stwierdzili, że świeże owoce aronii charakteryzują się najwyższą zdolnością przeciwutleniającą $(15,82 \div 16,02 \mathrm{mmol}$ Troloxu/100 g) w porównaniu z innymi owocami badanymi przez różnych autorów, w tym: bzu czarnego $(14,50 \mathrm{mmol} / 100 \mathrm{~g})$, borówki amerykańskiej $(6,01 \mathrm{mmol} / 100 \mathrm{~g})$, jeżyny $(5,57 \mathrm{mmol} / 100 \mathrm{~g})$, czarnej porzeczki $(5,67 \mathrm{mmol} / 100 \mathrm{~g})$, truskawki $(2,06 \mathrm{mmol} / 100 \mathrm{~g})$, maliny $(2,14 \mathrm{mmol} / 100 \mathrm{~g})$, żurawiny $(1,85 \mathrm{mmol} / 100 \mathrm{~g})$. Wymienieni autorzy zwrócili uwagę, że udział antocyjanów w całkowitej aktywności przeciwutleniającej wynosi ok. $33 \% \mathrm{w}$ przypadku świeżych jagód aronii. Wysoką aktywność przeciwutleniającą świeżych owoców aronii potwierdzili Rugina i wsp. [22] - na poziomie 9,59 $\div$ 17,17 mmol Troloxu/100 g. Aktywność przeciwutleniająca świeżego jarmużu wynosiła 1,175 mmol Troloxu/100 g [9]. Gramza-Michałowska i Człapka-Matyasik [5] porównały przekąski uzyskane z owoców liofilizowanych i wykazały silniejszą aktywność przeciwutleniaczy aronii w porównaniu z czarną porzeczką i truskawką. Oszmiański i wsp. [18] ocenili aktywność przeciwutleniającą proszków otrzymanych metodą liofilizacji z owoców żurawiny oraz z wytłoków i uzyskali wartości $\mathrm{ABTS}^{++}$niższe od wyników niniejszej pracy, odpowiednio [mmol TE/100g s.m.]: 19,45 i 27,52 $\div 21,78$. Witkowska i Zujko [27] określili aktywność przeciwutleniającą TEAC owoców leśnych suszonych w temp. $60{ }^{\circ} \mathrm{C}$ do suchej masy i uzyskali niższą niż w badaniach własnych aktywność przeciwutleniającą czarnej jagody (8,66 mg/100 g), żurawiny błotnej $(6,13 \mathrm{mg} / 100 \mathrm{~g})$, borówki brusznicy 
$(6,32 \mathrm{mg} / 100 \mathrm{~g})$, maliny $(14,24 \mathrm{mg} / 100 \mathrm{~g})$, poziomki $(11,80 \mathrm{mg} / 100 \mathrm{~g})$. Nawirska i wsp. [15] stwierdzili, przy zastosowaniu metody z ABTS ${ }^{++}$, niską aktywność przeciwutleniającą wytłoków z aronii $(5,32 \mathrm{mmol}$ Troloxu/100 g), porównywalną z czarną porzeczką i jagodą kamczacką (odpowiednio: 5,69 i 6,22 mmol Troloxu/100 g), ale jeszcze niższą charakteryzowały się owoce truskawki i pigwowca japońskiego $(2,33$ i 1,40 mmol Troloxu/100 g). Właściwości przeciwutleniające badanych wytłoków były znacznie niższe niż uzyskane w badaniach własnych w przypadku aronii, co prawdopodobnie jest związane $\mathrm{z}$ zastosowaną przez autorów metodą suszenia owiewowego, w trakcie którego zawartość związków o właściwościach przeciwutleniających ulega znaczącemu zmniejszeniu. Bober i Oszmiański [2] stwierdzili porównywalną aktywność przeciwrodnikową owoców i wytłoków aronii suszonych różnymi metodami. Przytoczone dane literaturowe są dość zróżnicowane, odbiegające często od wyników uzyskanych w badaniach własnych, co może wynikać z różnic odmianowych surowca, sposobu prowadzenia procesu liofilizacji, ilości ciepła dostarczanego podczas liofilizacji (temperatury półek), sposobu i czasu prowadzenia procesu rozdrabniania surowca, a także warunków przechowywania.

\section{Wnioski}

1. Metoda liofilizacji, a następnie mikronizacji surowców pochodzenia roślinnego pozwala uzyskać proszki bogate w związki bioaktywne, takie jak: witamina C, polifenole, w tym antocyjany, jak również karotenoidy, charakteryzujące się jednocześnie wysoką aktywnością przeciwutleniającą. Zawartość tych związków oraz właściwości przeciwutleniające były znacznie zróżnicowane w zależności od rodzaju badanego surowca.

2. Największą zawartością witaminy $\mathrm{C}$ charakteryzowały się proszki otrzymane z jarmużu, owoców rokitnika oraz z mieszanek owoców i warzyw (333 $486 \mathrm{mg} / 100 \mathrm{~g}$ ), natomiast zawartość witaminy $\mathrm{C}$ w proszkach z borówki czernicy i buraka była mała.

3. Liofilizowane proszki z owoców, szczególnie z aronii, borówki czernicy i z żurawiny zawierały dużo polifenoli ogółem $(620 \div 1876 \mathrm{mg} / 100 \mathrm{~g})$, w tym antocyjanów $(370 \div 1678 \mathrm{mg} / 100 \mathrm{~g})$, kilkakrotnie przewyższając zawartość polifenoli ogółem w badanych warzywach $(70 \div 361 \mathrm{mg} / 100 \mathrm{~g})$.

4. Aktywność przeciwutleniająca liofilizowanych proszków była zróżnicowana w zależności od rodzaju badanych surowców i zawartości w nich związków bioaktywnych, szczególnie polifenoli ogółem, antocyjanów oraz karotenoidów. Najwyższą aktywność przeciwutleniającą oraz największą zawartość związków bioaktywnych, tj. polifenoli, a szczególnie antocyjanów, wykazano w liofilizowanych owocach aronii i borówki czernicy. 
5. Proszki liofilizowane otrzymane $\mathrm{z}$ trawy jęczmiennej i pokrzywy charakteryzowały się dużą zawartością karotenoidów ogółem, w tym luteiny i zeaksantyny, przewyższającą znacznie ich zawartość w szpinaku i jarmużu. Zawierały one również dużo polifenoli ogółem oraz wykazywały wysoką aktywność przeciwutleniającą.

6. Uzyskane wyniki wskazują, że proszki otrzymane metodą liofilizacji mogą być szeroko wykorzystywane do produkcji żywności funkcjonalnej, żywności specjalnego przeznaczenia żywieniowego i suplementów diety, nie tylko jako cenne substancje smakowe, ale również jako dodatki bogate w naturalne substancje bioaktywne zwiększające ich wartość odżywczą.

Badania zrealizowano w Katedrze Żywności Funkcjonalnej, Ekologicznej i Towaroznawstwa, Wydziat Nauk o Żywieniu Człowieka i Konsumpcji, Szkoła Gtówna Gospodarstwa Wiejskiego w Warszawie.

\section{Literatura}

[1] Biegańska-Marecik R., Radziejewska-Kubzdela E., Marecik R.: Characterization of phenolics, glucosinolates and antioxidant activity of beverages based on apple juice with addition of frozen and freeze-dried curly kale leaves (Brassica oleracea L. var. acephala L.). Food Chem., 2017, 230, 271 280.

[2] Bober I., Oszmiański J.: Zastosowanie wytłoków aronii do naparów herbat owocowych, Acta Sci. Pol. Technol. Aliment., 2004, 1 (3), 63-72.

[3] Dembczyński R., Białas W., Olejnik A., Kowalczewski P., Drożdżyńska A., Jankowski T.: Separacja antocyjanów z owoców aronii, czarnego bzu, czarnej porzeczki i korzenia czarnej marchwi za pomocą chromatografii preparatywnej. Żywność. Nauka. Technologia. Jakość, 2015, 6 (103), 41-52.

[4] Frejnagel S.: Comparison of polyphenolic composition of extracts from honeysuckle, chokeberries and green tea - a short report. Pol. J. Food Nutr. Sci., 2007, 57 (1), 83-86.

[5] Gramza-Michałowska A., Człapka-Matyasik M.: Evaluation of the antiradical potential of fruit and vegetable snacks. Acta Sci. Pol., Technol. Aliment., 2011, 10 (1), 61-72.

[6] Jakobek L., Šeruga M., Medvidović-Kosanović M., Novak I.: Antioxidant activity and polyphenols of aronia in comparison to other berry species. Agric. Consp. Scient., 2007, 4 (72), 301-306.

[7] Karam M., Petit J., Zimmer D., Djantou E.B., Scher J.: Effects of drying and grinding in production of fruit and vegetable powders: A review. J. Food Eng., 2016, 188, 32-49.

[8] Kluszczyńska D., Sowińska W.: Wpływ procesów technologicznych na zawartość substancji bioaktywnych w owocach borówki czernicy. Żywność. Nauka. Technologia. Jakość, 2014, 4 (95), 30-42.

[9] Korus A., Lisiewska Z.: Effect of preliminary processing and method of preservation on the content of selected antioxidative compounds in kale (Brassica oleracea L. var. acephala) leaves. Food Chem., 2011, 129, 149-154.

[10] Kulling S.E, Rawel H.M.: Chokeberry (Aronia melanocarpa) - A review on the characteristic components and potential health effects. Planta Med., 2008, 74, 1625-1634.

[11] Liapis A.I., Bruttini R.: Freeze Drying. In: Handbook of Industrial Drying. $4^{\text {th }}$ ed. Ed. A.S. Mujumdar. CRC Press, Boca Raton 2014.

[12] Lin T.M., Durance T.D., Scaman C.H.: Characterization of vacuum microwave, air and freeze dried carrot slices. Food Res. Int., 1998, 31 (2), 111-114. 
[13] Mahn A., Zamorano M., Reyes A.: Effect of freeze-drying conditions on antioxidant compounds of broccoli. J. Food Process. Technol., 2014, 5 (8), 5-8.

[14] Marques L.G., Freire J.T.: Freeze-drying characteristics of tropical fruits. Dry Technol, 2006, 24, 17.

[15] Nawirska A., Sokół-Łętowska A., Kucharska A.Z.: Właściwości przeciwutleniające wytłoków z wybranych owoców kolorowych. Żywność. Nauka. Technologia. Jakość, 2007, 4 (53), 120-125.

[16] Nireesha G.R., Divya L., Sowmya C., Venkateshan N., Niranjan Babu M., Lavakumar V.: Lyophilization: Freeze drying - an review. Int. J. Novel Trends Pharm. Sci., 2013, 4 (3), 87-98.

[17] Oszmiański J., Wojdylo A.: Aronia melanocarpa phenolics and their antioxidant activity. Eur. Food Res. Technol., 2005, 221 (6), 809-813.

[18] Oszmiański J., Kolniak-Osteka J., Lachowicz S., Gorzelany J., Matłok N.: Effect of dried powder preparation process on polyphenolic contentand antioxidant capacity of cranberry (Vaccinium macrocarpon L.). Industrial Crops and Products, 2015, 77, 658-665.

[19] Pellegrini N., Serafini M., Colombi B., Del Rio D., Salvatore S., Bianchi M., Brighenti F.: Total antioxidant capacity of plant foods, beverages and oils consumed in Italy assessed by three different in vitro assays. J. Nutr, 2003, 133, 2812-2819.

[20] Piłat B., Zadernowski R., Bieniek A.: Charakterystyka chemiczna różnych odmian rokitnika. Bromat. Chem. Toksykol., 2012, 3 (45), 897-901.

[21] Que F., Mao L., Fang X., Wu T.: Comparison of hot air-drying and freeze-drying on the physicochemical properties and antioxidant activities of pumpkin (Cucurbita moschata Duch.) flours. Int. J. Food Sci. Technol., 2008, 43, 1195-1201.

[22] Rugină D., Sconţa Z., Leopold L., Pintea A., Bunea A., Socaciu C.: Antioxidant activities of chokeberry extracts and the cytotoxic action of their anthocyanin fraction on HeLa human cervical tumor cells. J. Med. Food., 2012, 8 (15), 700-706.

[23] Sablani S.S., Andrews P.K., Davies N.M., Walters T., Saez H., Bastar L.: Effects of air and freeze drying on phytochemical content of conventional and organic berries. Drying Technology, 2011, 2 (29), 205-216.

[24] Sadowska A., Świderski F., Rakowska R., Hallmann E.: The functional properties of chokeberry and kale powders obtained by an innovative method of fluidised-bed jet milling with drying compared to freeze drying, Int. J. Food Eng., 2017, 6 (13), DOI: 10.1515/ijfe-2016-0310.

[25] Samoticha J., Wojdyło A., Lech K.: The influence of different the drying methods on chemical composition and antioxidant activity in chokeberries. LWT - Food Sci. Technol., 2016, 66, 484-489.

[26] Teleszko M., Wojdyło A., Rudzińska M., Oszmiański J., Golis T.: Analysis of lipophilic and hydrophilic bioactive compounds content in sea buckthorn (Hippophaë rhamnoides L.) berries. J. Agric. Food Chem., 2015, 63 (16), 4120-4129.

[27] Witkowska A., Zujko M.E.: Aktywność antyoksydacyjna owoców leśnych. Bromat. Chem. Toksykol., 2009, 3 (42), 900-903.

[28] Wojdyło A., Figiel A., Lech K., Nowicka P., Oszmianski J.: Effect of convective and vacuum- microwave drying on the bioactive compounds, color, and antioxidant capacity of sour cherries. Food Bioprocess Technol., 2014, 7, 829-841. 


\title{
ASSESSING CONTENTS OF BIOACTIVE CONSTITUENTS AND ANTIOXIDANT PROPERTIES OF POWDERS PRODUCED FROM SELECTED PLANT MATERIALS BY FREEZE-DRYING METHOD
}

\author{
S u m mary
}

The objective of the research study was to assess the contents of vitamin C, polyphenols, and carotenoids, and to determine the antioxidant properties of industrially produced powders from selected plant materials using a freeze-drying method followed by micronisation. Twelve powders were analyzed: fruit $\&$ vegetable powders, nettle powder and barley grass powder; all of them enjoy a growing consumer interest. The contents of vitamin C, various polyphenol fractions, and carotenoids were determined by a highperformance liquid chromatography (HPLC) and the antioxidant properties by a spectrophotometric method using synthetic $\mathrm{ABTS}^{+}$cation radicals.

Depending on the type of plant materials analyzed, the powders produced were characterized by a diversified, rather high content of bioactive substances tested and by the antioxidant activity. The highest content of vitamin $\mathrm{C}$ was found in powders from sea buckthorn and kale fruits (333 and $348 \mathrm{mg} / 100 \mathrm{~g}$, respectively) and in powders from a mixture of red fruits and vegetables (486 mg / $100 \mathrm{~g}$ ). The chokeberry and blueberry powders were characterized by the highest content of total polyphenols and the highest antioxidant activity.

Based on the research results obtained, it was found that, depending on the nature of the powders produced, they can be applied to make functional food, food for particular nutritional uses, and dietary supplements; those powders can be applied not only for their sensory qualities but, also, because they contain valuable constituents: natural vitamin $\mathrm{C}$, polyphenols, and carotenoids.

Key words: freeze-drying, vitamin C, polyphenols, antioxidant activity, powders 